\title{
Pseudomonas pomi Cole 1959 Is a Later Subjective Synonym of Acetobacter pasteurianus (Hansen 1879) Beijerinck 1898, and Pseudomonas melophthora Allen and Riker 1932 is a Nomen Dubium
}

\author{
B. N. DHANVANTARI, ${ }^{1}$ D. W. DYE, ${ }^{2}$ AND J. M. YOUNG ${ }^{2}$ \\ Agriculture Canada, Research Station, Harrow, Ontario, Canada NOR 1GO, ${ }^{1}$ and Plant Diseases Division, \\ Department of Scientific and Industrial Research, Auckland, New Zealand ${ }^{2}$
}

An examination of all known strains labeled Pseudomonas melophthora Allen and Riker 1932 and of the herein-designated type strain of $P$. pomi Cole 1959 (strain PDDCC 3878 [= NCPPB 463]) showed that they were similar to one another but atypical of members of the genus Pseudomonas Migula 1894. Because these organisms were found to be either motile (peritrichous cells) or nonmotile, able to grow at low $\mathrm{pH}$ values, and to oxidize ethanol and lactate to carbonate, it is suggested that they belong to Acetobacter Biejerinck 1898. P. pomi is regarded here as being a subjective junior synonym of $A$. pasteurianus (Hansen 1897) Beijerinck 1898, and $P$. melophthora is regarded here as being a nomen dubium. Isolates of $P$. pomi and similar organisms capable of inducing necrosis in apple fruit should be classified in $A$. pasteurianus until the relationships of pathogenic strains within the species are better understood.

Pseudomonas melophthora Allen and Riker (1) was first reported in the United States as causing a firm brown discoloration of apple (Malus pumila Mill.) fruit tissue after invasion by apple maggots. It and another bacterial pathogen, Pseudomonas pomi Cole (7), were later reported in England. The latter organism produced a similar effect but, unlike $P$. melophthora, it was encapsulated and nonmotile. Cole deposited isolates of both of these organisms with the National Collection of Plant Pathogenic Bacteria (NCPPB), Harpenden, England. One isolate of $P$. pomi and two identified as $P$. melophthora, all from the NCPPB, were the only strains of these species available for study.

In their revision of Pseudomonas Migula (25), Doudoroff and Palleroni (11) included P. melophthora in an addendum containing a list of incompletely described species and placed $P$. pomi in an addendum containing a list of species known to possess characters not in accord with the generic definition; as such, these organisms were regarded as species incertae sedis. Dye et al. (13) suggested that all validly published names of plant pathogenic species of Pseudomonas for which there are isolates be retained until further studies have established their relationships accurately. This paper reports a taxonomic study of $P$. pom $i$ and of strains identified as belonging to $P$. melophthora.

\section{MATERLALS AND METHODS}

Bacterial strains. P. melophthora PDDCC 4167 and PDDCC 4168 (PDDCC: Plant Diseases Division Culture Collection Department of Scientific and Industrial Research, Auckland, New Zealand) (= NCPPB 461 and NCPPB 462, respectively) and $P$. pomi PDDCC 3878 ( = NCPPB 463) were obtained from the PDDCC as freeze-dried cultures.

Media. For routine testing, cells were subcultured on potato-dextrose agar (Difco Laboratories) and incubated for 4 to 7 days at $25^{\circ} \mathrm{C}$. Unless otherwise indicated, faintly turbid suspensions (ca. $10^{8}$ colonyforming units per $\mathrm{ml}$ ) were prepared in sterile distilled water for the inoculation of broth and agar media.

Growth of cultures was compared on: nutrient agar; potato-dextrose agar; yeast-salts agar (12) containing $2 \%$ glucose; and alcohol-yeast extract-tryptone agar (3\% ethanol, $0.5 \%$ yeast extract [Difco], $1 \%$ tryptone [Difco], 1.5\% agar; pH 6.5).

Gram reaction, motility, and flagellation. The Hucker modification of the Gram stain was used, in which Lugol iodine replaced Burke iodine (27). The periods of staining, mordanting, counter-staining, and rinsing were carefully timed (3).

Motility was determined with 48-h-old shake cultures (yeast-salts-2\% glucose broth) observed with a phase-contrast microscope. Flagella were stained by the method of Lowy and Hanson (24) and were examined with a Joel JEM 100B electron microscope.

Oxygen requirements. Each organism was inoculated into two tubes of potato-dextrose agar, one of which was placed in a Torbal jar rendered anaerobic with a GasPak (BBL Microbiology Systems, Cockeys- 
ville, Md.) and held at $25^{\circ} \mathrm{C}$; the other was placed in an incubator at $25^{\circ} \mathrm{C}$ as a check. Strains which showed visible growth after 14 days in the Torbal jar were recorded as being anaerobic. Cultures that failed to grow in anaerobic conditions were considered to to aerobes.

The use of nitrate as an alternative electron acceptor (nitrate respiration) was tested by the method of Iizuka and Komagata (19). Cultures that failed to grow in the anaerobic conditions of this test were considered to be obligate aerobes.

Glucose fermentation was tested by the method of Hugh and Leifson (18).

Other determinative tests. Production of fluorescent pigment was tested on King medium B (20).

The LOPAT tests (levan production, oxidase reaction, potato rot, arginine dihydrolase activity, and tobacco hypersensitivity reaction) were made by the methods of Lelliott et al. (23).

Production of poly- $\beta$-hydroxybutyrate inclusions was determined by the Hayward (17) modification of the Burdon (5) method.

Growth on alcohol in Hoyer-Frateur medium was determined by the method of De Ley and Frateur (10).

Growth at $\mathrm{pH} 4.5$ was tested in apple juice (sp gr, 1.0) depectinized by ultrafiltration and fortified with $0.5 \%$ yeast extract. Seven-milliliter quantities of this medium (in $16-\mathrm{mm}$ culture tubes) were sterilized by filtration and were inoculated and incubated as shake cultures at room temperature $\left(20\right.$ to $\left.22^{\circ} \mathrm{C}\right)$ for 7 days.

Production of acetic acid was examined in alcohol-yeast-extract broth and in ethanol-carbonate agar at $\mathrm{pH} 6.5$ and 7.2. Oxidation of calcium lactate to carbonate and production of dihydroxyacetone (ketogenesis) from glycerol were tested for by the methods of Skerman (26).

Also tested were formation of gluconate and cellulose (6), production of 2-keto-D-gluconate (23), production of acetylmethylcarbinol (acetoin) and catalase (12), and tolerance to potassium cyanide (14). The methyl red test (12) was also performed.

Nutritional and other tests. For nutritional screening, the methods followed were those described by R. A. Lelliott in Interlaboratory Study of LOPAT Group 1 Plant Pathogenic Pseudomonads (circulated in 1974 by the author, Ministry of Agriculture, Fisheries and Food, Plant Pathology Laboratory, Hatching Green, Harpenden, Herts, U.K.). The carbon compounds were added to a basal medium ( $\mathrm{pH} 7.2$ ) containing: $\mathrm{NH}_{4} \mathrm{H}_{2} \mathrm{PO}_{4}, 1 \mathrm{~g} ; \mathrm{KCl}, 0.2 \mathrm{~g} ; \mathrm{MgSO}_{4} \cdot 7 \mathrm{H}_{2} \mathrm{O}, 0.2$ g; agar (Davis, Christchurch, New Zealand), 12 g; and distilled water, 1 liter. Concentrated solutions of carbohydrates were filter-sterilized and added to the basal medium after autoclaving, to give a final concentration of $0.5 \%$ (wt/vol). Amino acids and organic acids were autoclaved with the basal medium to give a final concentration of $0.2 \%(\mathrm{wt} / \mathrm{vol})$. Petri plates were poured thick using $30 \mathrm{ml}$ of medium per plate. The carbohydrates and related carbon compounds tested were arabinose, rhamnose, xylose, dextrose, fructose, galactose, mannose, ribose, lactose, sucrose, maltose, trehalose, melibiose, cellobiose, raffinose, melezitose, starch, glycerol, erythritol, adonitol, mannitol, sorbitol, dulcitol, meso-inositol, arbutin, salicin, and $\alpha$ -
methyl-D-glucoside. The amino acids D-alanine, L-leucine, and DL-homoserine and sodium salts of the organic acids $\mathrm{L}-(+)$-tartrate, D-(-)-tartrate, formate, malonate, gluconate, and DL-lactate were used. The plates were inoculated, 14 patches per plate, with a multipoint inoculator. Growth greater than that on basal medium was scored as positive at 3-, 5-, 7-, 14-, and 21-day intervals.

Tests for proteolysis of gelatin: action in purple milk; presence of urease; production of $\mathrm{H}_{2} \mathrm{~S}$ (from cysteine, peptone, and sodium thiosulfate), ammonia, indole, and nitrite from nitrate; and utilization of asparagine as a sole source of carbon and nitrogen were performed by the methods of Dye (12). Tests for arbutin hydrolysis and the presence of tyrosinase were made by the methods of Crosse and Garrett (8).

Growth at 30 and $34^{\circ} \mathrm{C}$ was tested by inoculating and incubating yeast-salts- $2 \%$ glucose broth tubes in constant-temperature water baths.

Pathogenicity tests. Ripe apple (common name, "Granny Smith") fruits were surface-sterilized with $70 \%$ ethanol and pricked, 1 to $2 \mathrm{~cm}$ deep, at three sites per fruit with a hypodermic needle charged with bacterial suspension. Controls were prepared by inoculating fruit with sterile distilled water. The fruits were enclosed in polythene bags and incubated at $25^{\circ} \mathrm{C}$ for 4 weeks.

\section{RESULTS}

In pathogenicity tests, all three strains (PDDCC 3878, 4167, and 4168) inoculated into Granny Smith apples produced a similar discoloration of fruit tissue. The effect was evident as a circular brown patch around the point of inoculation within 1 week and extended on the surface as well as inside the fruit without causing collapse of tissue. The tissue inside the fruit was brown, forming a definite margin with adjacent white portions of unaffected tissue.

Nutrient agar proved to be unsuitable for culturing these bacteria, as growth was hardly evident on this medium after 7 days. Although growth was slow on potato-dextrose agar and alcohol-yeast extract-tryptone agar, these media were more suitable than nutrient agar. The colonies on these media were convex, 1 to $2 \mathrm{~mm}$ in diameter after 7 days, and up to $4 \mathrm{~mm}$ in diameter in 14 days. The colonies were pearly white on potato-dextrose agar and mauve on alcohol-yeast extract-tryptone agar; the smell of acetic acid emanated from inoculated plates of the latter medium.

Young cultures of the P. melophthora and $P$. pomi strains contained gram-negative, obligately aerobic cells. Cells of $P$. pom $i$ PDDCC 3878 were oval and nonflagellated and appeared to have a capsule-like structure (Fig. 1). Cells of $P$. melophthora PDDCC 4167 and 4168 were slightly bent, peritrichous rods (Fig. 2).

The cultures did not produce fluorescent pig- 


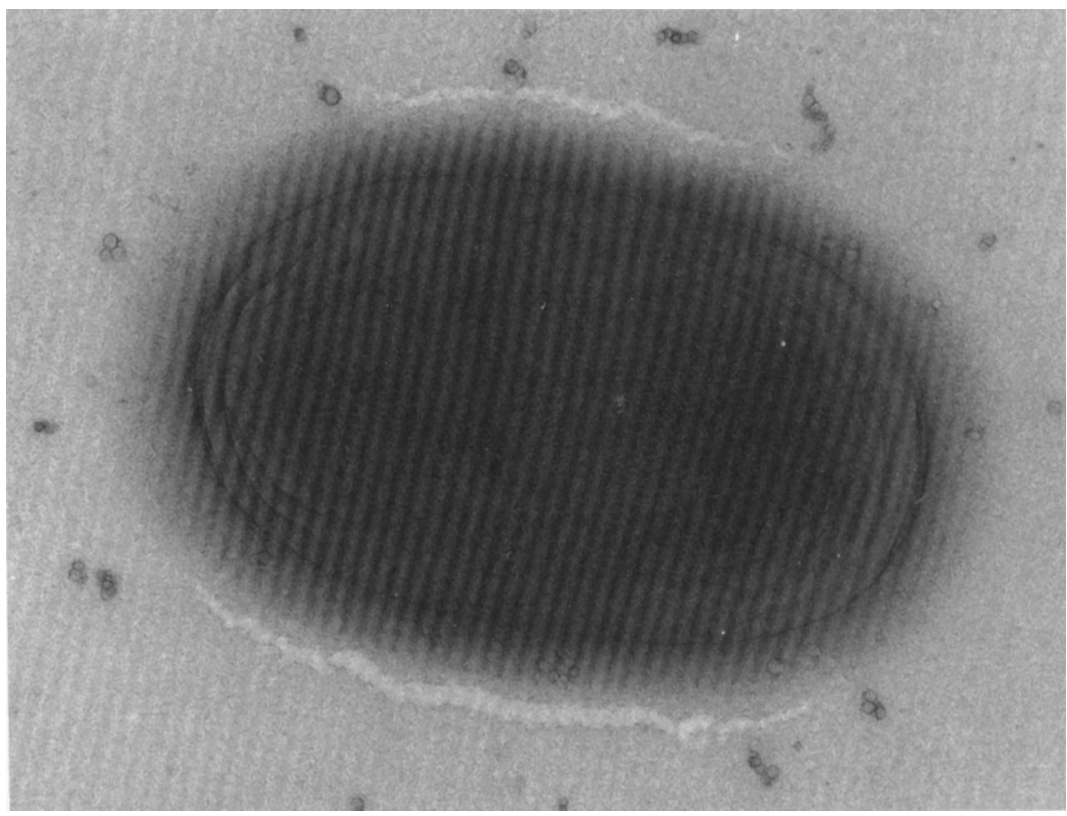

FIG. 1. Electron micrograph of cell of PDDCC 3878 (P. pomi). $\times 43,000$.

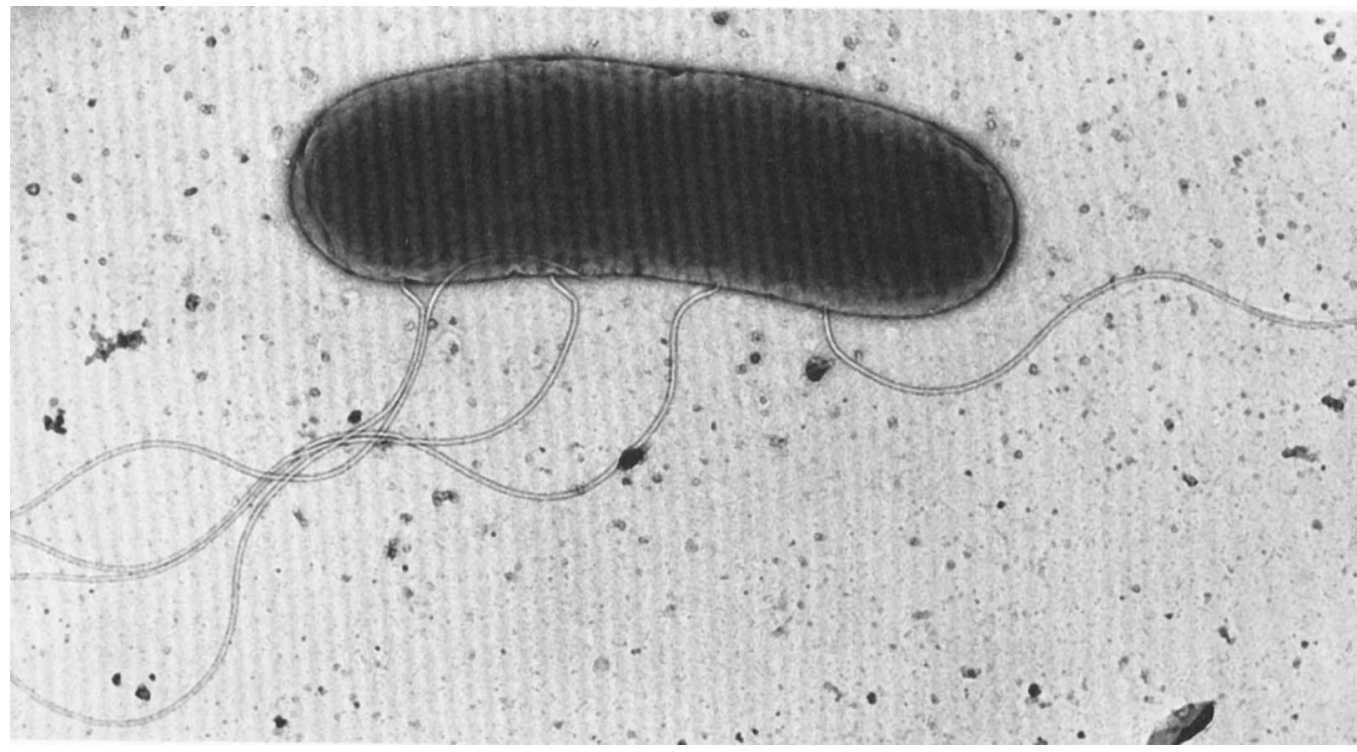

FiG. 2. Electron micrograph of cell of PDDCC 4167 (P. melophthora). $\times 23,237$ ).

ment in King medium B, were negative in all LOPAT tests, and did not produce poly- $\beta$-hydroxybutyrate inclusions.

All cultures grew in apple juice at $\mathrm{pH} 4.5$ and oxidized ethanol to acetic acid in 2 to 4 days in alcohol-yeast extract broth and agar media at $\mathrm{pH} 6.5$ but not at $\mathrm{pH}$ 7.2. A zone of reprecipitated calcium carbonate appeared around the bacte- rial growth in ethanol-carbonate agar within 5 days, indicating oxidation of ethanol to acetic acid and then to $\mathrm{CO}_{2}$. Oxidation of lactate to $\mathrm{CO}_{2}$ was observed after 5 days.

All strains were catalase positive, produced gluconate, and grew with ethanol. Dihydroxyacetone was not produced in glycerol medium (no ketogenesis), and the cultures did not pro- 
duce 2-keto-D-gluconate or cellulose. All three strains produced gluconate and were able to grow with ethanol in Hoyer-Frateur medium within 5 to 7 days.

All of the strains of $P$. melophthora and $P$. pomi utilized glucose, ribose, glycerol, meso-inositol, salicin, D-alanine, and DL-lactate but were not shown to utilize rhamnose, lactose, maltose, raffinose, adonitol, dulcitol, arbutin, $\alpha$-methylD-glucoside, L-leucine, DL-homoserine, L- $(+)$ tartrate, $D-(-)$-tartrate, formate, malonate, or gluconate. Strain 3878 (P. pomi) was the only one to show utilization of galactose, fructose, mannose, xylose, sucrose, trehalose, and sorbitol; it gave weak reactions with arabinose, cellobiose, melibiose, melezitose, erythritol, and mannitol.

The cultures of $P$. melophthora and of $P$. pomi were urease positive and grew at $30^{\circ} \mathrm{C}$ but not at $34^{\circ} \mathrm{C}$. They did not hydrolyze arbutin, gelatin, or casein (in purple milk) and did not produce acetoin, ammonia, or indole, reduce niproduce acetoin, ammonia, or indole, reduce nitrate to nitrite, tolerate $\mathrm{KCN}$, or utilize asparagine as a sole source of carbon and nitrogen; they did not possess tyrosinase and were negative in the methyl red test.

\section{DISCUSSION}

The isolates received as $P$. melophthora and that received as $P$. pomi produced a brown discoloration of apple tissue identical with that originally described for $P$. melophthora and $P$. pomi. This ability is a major determinative character of these species. Although both Allen and Riker (1) and Cole (7) referred to the symptom of these pathogens as a "rot," neither organism exhibited pectinolytic activity, the primary symptom being a necrosis of fruit tissue.

Although the strains received as $P$. melo- phthora were motile and peritrichous and that received as $P$. pomi was nonmotile, the cultures gave similar reactions in most tests, and it is concluded that these isolates should be classified in one species. The flagellar arrangement of strains identified as $P$. melophthora excludes them from Pseudomonas, and it is therefore concluded that these organisms are improperly classified in this genus (Table 1).

The observation that the strains studied were acid tolerant and oxidized ethanol to acetic acid indicates their similarity to organisms in the genera Acetobacter Beijerinck (4) and Gluconobacter Asai (2) (formerly Acetomonas Leifson [22]). [The generic name Acetobacter and the species $A$. pastorianus (sic) were first mentioned incidentally by Beijerinck (1898). No other authority seems more appropriate in light of the confused origin of this genus.] A comparison of the determinative characters of the strains with those given by De Ley and Frateur (9) for Acetobacter and Gluconobacter indicates that the cultures are members of Acetobacter (Table 1).

From the key given by De Ley and Frateur (10) for species of Acetobacter (Table 2), it is apparent that the isolates tested are representatives of $A$. pasteurianus (Hansen 1879) (16) Beijerinck 1898 (4).

Cole (7) did not designate a type strain for $P$. pomi. However, because PDDCC 3878 was the only strain described by him, this strain is the type (monotype) (Bacteriological Code, Rule 18c [21]). $P$. pomi is therefore a subjective junior synonym of $A$. pasteurianus.

Allen and Riker (1) did not designate a type strain for $P$. melophthora, and none of the strains on which they based their original description of this species is known to exist. Because the strains identified as $P$. melophthora by Cole (7) have been shown here to belong in

TABLE 1. Comparison of characters of P. melophthora strains and P. pomi with those of Pseudomonas, Gluconobacter, and Acetobacter ${ }^{a}$

\begin{tabular}{|c|c|c|c|c|c|}
\hline Character & $\begin{array}{l}\text { Pseudo- } \\
\text { monas }\end{array}$ & $\begin{array}{c}\text { Glucono- } \\
\text { bacter }\end{array}$ & Acetobacter & P. melophthora & P. pomi \\
\hline Flagella & + (polar) & $+($ polar $) /-$ & + (peritrichous) $/-$ & + (peritrichous) & - \\
\hline Growth at $\mathrm{pH} 4.5$ & - & + & + & + & + \\
\hline \multicolumn{6}{|l|}{ Oxidation of: } \\
\hline Ethanol to acetic acid & $-^{*}$ & $+^{*}$ & $t^{*}$ & $+^{* *}$ & $+^{* *}$ \\
\hline Acetic acid to $\mathrm{CO}_{2}$ & $\mathrm{~d}$ & - & + & + & + \\
\hline Lactate to $\mathrm{CO}_{2}$ & + & - & + & + & + \\
\hline Ketogenesis & - & + & d & - & - \\
\hline \multicolumn{6}{|l|}{ Hydrolysis of: } \\
\hline Lactose & $\mathrm{d}$ & - & - & - & - \\
\hline Starch & $\mathrm{d}$ & - & - & - & - \\
\hline Gelatin & $\mathrm{d}$ & $-/ w$ & - & - & - \\
\hline
\end{tabular}

${ }^{a}$ Characters of Pseudomonas, Gluconobacter, and Acetobacter from De Ley and Frateur (9). Symbols: + , Positive; -, negative; w, weak; d, 11 to $89 \%$ strains positive; $\left(\quad\right.$ ), usually positive or negative; ${ }^{*}, \mathrm{pH} 4.5{ }^{* *}, \mathrm{pH}$ 6.5 . 
TABLE 2. Comparison of characters of P. melophthora strains and P. pomi with those of species and subspecies of Acetobacter ${ }^{a}$

\begin{tabular}{|c|c|c|c|c|c|c|c|c|}
\hline Character & $\begin{array}{l}\text { P. melo- } \\
\text { phthora and } \\
\text { P. pomi }\end{array}$ & $\begin{array}{l}\text { A. pasteuri- } \\
\text { anus subspe- } \\
\text { cies pasteu- } \\
\text { rianus }\end{array}$ & $\begin{array}{l}\text { A.pasteuri- } \\
\text { anus subspe } \\
\text { cies lovan- } \\
\text { iensis }\end{array}$ & $\begin{array}{l}\text { A. pasteuri- } \\
\text { - anus subspe- } \\
\text { cies estunen- } \\
\text { sis }\end{array}$ & $\begin{array}{c}\text { A. pasteuri- } \\
\text { anus subspe } \\
\text { cies ascen- } \\
\text { dens }\end{array}$ & $\begin{array}{l}\text { A. pasteuri- } \\
\text {-anus subspe- } \\
\text { cies para- } \\
\text { doxus }\end{array}$ & $\begin{array}{l}\text { A. peroxy. } \\
\text { dans }\end{array}$ & A. aceti \\
\hline Catalase production & + & + & + & + & + & - & - & + \\
\hline $\begin{array}{l}\text { Ketogenesis in glyc- } \\
\text { erol }\end{array}$ & - & - & - & - & - & - & - & + \\
\hline \multicolumn{9}{|l|}{ Formation of: } \\
\hline $\begin{array}{l}\text { 2-Keto-D-gluco- } \\
\text { nate }\end{array}$ & - & d & - & $\mathrm{NT}^{b}$ & - & - & - & + \\
\hline Cellulose & - & - & - & + & - & - & - & $(-)$ \\
\hline Gluconate & + & $(+)$ & + & + & - & - & - & + \\
\hline Growth on ethanol & + & $(-)$ & + & + & - & - & + & d \\
\hline
\end{tabular}

${ }^{a}$ Acetobacter sp. and subsp. characters from De Ley and Frateur (10). For an explanation of the symbols, see footnote $a$ of Table 1 .

${ }^{b}$ NT, Not tested.

Acetobacter, there are no known strains identifiable with the species. Because Allen and Riker's (1) description is not adequate to identify the organism uniquely according to current classificatory criteria, the name $P$. melophthora is considered to be a nomen dubium according to Rule 56a(2) of the Bacteriological Code (21).

The genus Acetobacter is in need of taxonomic revision (10). When this revision is carried out, comparative pathogenic, biochemical, and nutritional tests will show whether all elements of $A$. pasteurianus are responsible for the necrotic reaction in apples or whether the disease is caused by a distinct pathogenic variant.

\section{ACKNOWLEDGMENTS}

B. N. Dhanvantari thanks Agriculture Canada for the grant of study transfer to New Zealand, where this work was done. We acknowledge the receipt of Pseudomonas melophthora and $P$. pomi cultures from the National Collection of Plant Pathogenic Bacteria, Ministry of Agriculture, Fisheries and Food, Plant Pathology Laboratory, Hatching Green, Harpenden, Herts, England, and thank R. Luketina for technical assistance.

\section{REPRINT REQUESTS}

Address reprint requests to: Dr. B. N. Dhanvantari, Agriculture Canada, Research Station, Harrow, Ontario, Canada NOR 190.

\section{LITERATURE CITED}

1. Allen, T. C., and A. J. Riker. 1932. A rot of apple fruit caused by Phytomonas melophthora n.sp., following invasion by the apple maggot. Phytopathology 22:557-571.

2. Asai, T. 1935. Taxonomic studies on acetic acid bacteria and allied oxidative bacteria isolated from fruits. A new classification of the oxidative bacteria. J. Agr. Chem. Soc. Jpn. 11:499-513, 610-620, 674-708.

3. Bartholomew, J. W. 1962. Variables influencing results, and the precise definition of steps in Gram staining as a means of standardizing the results obtained. Stain Technol. 37:139-155.

4. Beijerinck, M. W. 1898. Kral's Sammlung von Mikroorganismen, Prague. Cited in R. E. Buchanan (ed.), Monographs on systematic bacteriology, 1 . General system- atic bacteriology. The Williams \& Wilkins Co., Baltimore.

5. Burdon, K. L. 1946. Fatty material in bacteria and fungi revealed by staining dried, fixed slide preparations. $J$. Bacteriol. 52:665-678

6. Carr, J. G. 1968. Methods for identifying acetic acid bacteria, p. 1-8. In B. M. Gibbs and D. A. Shapton (ed.), Identification methods for microbiologists, part B. Academic Press Inc., London.

7. Cole, M. 1959. Bacterial rotting of apple fruit. Ann. Appl. Biol. 47:601-611.

8. Crosse, J. E., and C. M. E. Garrett. 1963. Studies on the bacteriophagy of Pseudomonas mors-prunorum, $P$ s. syringae and related organisms. J. Appl. Bacteriol. 26:159-177.

9. De Ley, J., and J. Frateur. 1974. Genus IV. Gluconobacter Asai 1935, 689, p. 251-253. In R. E. Buchanan and N. E. Gibbons (ed.), Bergey's manual of determinative bacteriology, 8 th ed. The Williams \& Wilkins Co., Baltimore.

10. De Ley, J., and J. Frateur. 1974. Genus Acetobacter Beijerinck 1898, 215, p. 276-278. In R. E. Buchanan and N. E. Gibbons (ed.), Bergey's manual of determinative bacteriology, 8th ed. The Williams \& Wilkins Co., Baltimore.

11. Doudoroff, M., and N. J. Palleroni. 1974. Genus 1. Pseudomonas Migula 1894, 237, p. 217-243. In R. E. Buchanan and N. E. Gibbons (ed.), Bergey's manual of determinative bacteriology, 8th ed. The Williams \& Wilkins Co., Baltimore.

12. Dye, D. W. 1968. A taxonomic study of the genus Erwinia. 1. The "amylovora" Group. N. Z. J. Sci. 11:590-607.

13. Dye, D. W., J. F. Bradbury, R. S. Dickey, M. Goto, C. N. Hale, A. C. Hayward, A. Kelman, R. A. Lelliott, P. N. Patel, D. C. Sands, M. N. Schroth, D. R. W. Watson, and J. M. Young. 1975. Proposals for a reappraisal of the status of names of plant-pathogenic Pseudomonas species. Int. J. Syst. Bacteriol. 25:252-257.

14. Edwards, P. R., and M. A. Fife. 1956. Cyanide media in the differentiation of enteric bacteria. Appl. Microbiol. 4:46-48.

15. Frateur, J. 1950. Essai sur la systématique des acetobacters. Cellule 53:287-392.

16. Hansen, E. C. 1879. Bidrag til kundskab om hvilke organismer der kunne forekommer og level i øl og Ølurt. Medd. Carlsberg Lab. 1:185-234.

17. Hayward, A. C. 1964. Characteristics of Pseudomonas solanacearum. J. Appl. Bacteriol. 25:265-277. 
18. Hugh, R., and E. Leifson. 1953. The taxonomic significance of fermentative versus oxidative metabolism of carbohydrates by various gram negative bacteria. J. Bacteriol. 66:24-26.

19. Iizuka, H., and K. Komagata. 1963. An attempt at grouping Pseudomonas. J. Gen. Appl. Microbiol. 9:73-82.

20. King, E. O., M. K. Ward, and D. E. Raney. 1954. Two simple media for the demonstration of pyocyanin and fluorescin. J. Lab. Clin. Med. 44:301-307.

21. S. P. Lapage, P. H. A. Sneath, E. F. Lessel, V. B. D. Skerman, H. P. R. Seeliger, and W. A. Clarke (ed.). 1975. International code of nomenclature of bacteria. 1976 Revision. American Society for Microbiology, Washington, D.C

22. Leifson, E. 1954. The flagellation and taxonomy of species of Acetobacter. Antonie van Leeuwenhoek J. Microbiol. Serol. 20:102-110.

23. Lelliott, R. A., E. Billing, and A. C. Hayward. 1966. A determinative scheme for the fluorescent plant pathogenic pseudomonads. J. Appl. Bacteriol. 29:470-489.

24. Lowy, J., and J. Hanson. 1965. Electron microscope studies of bacterial flagella. J. Mol. Biol. 11:293-313.

25. Migula, W. 1894. Uber ein neues System der Bakterien. Arb. Bakteriol. Inst. Tech. Hochsch. Karlsruhe 1:235-238.

26. Skerman, V. B. D. 1967. A guide to the identification of the genera of bacteria, 2nd ed. The Williams \& Wilkins Co., Baltimore.

27. Society of American Bacteriologists. 1957. Manual of microbiological methods. McGraw-Hill Book Co., Inc., New York. 